\title{
The phyllostomid bat (Mammalia, Chiroptera) assemblage in a fragmented landscape in Midwestern Brazil
}

\author{
Anderson Odon (1), Marcelo O. Bordignon (1) \& Guilherme D. P. Dornelles (1)
}

Laboratório de Zoologia, Instituto de Biociências, Programa de Pós-Graduação em Biologia, Universidade Federal de Mato Grosso do Sul, 79002-900 Campo Grande, MS, Brazil. (anderson.odon@hotmail.com)

\author{
Received 19 September 2018 \\ Accepted 12 March 2019 \\ Published 23 May 2019 \\ DOI 10.1590/1678-4766e2019015
}

\begin{abstract}
Bats are the second largest order of mammals, with varying feeding habits and great ecological significance. Anthropization has several important effects on animal communities and the Brazilian Cerrado, a Neotropical savannah, has been severely affected by human activity. The objective of this study was to evaluate phyllostomid bat assemblage distributions in the different landscape formations of a modified savannah. Using mist nets, we performed 36 sampling nights between 2015 and 2016. The sampling effort was $23,328 \mathrm{~m}^{2} . \mathrm{h}$ and was equally distributed over three landscape formations: a large fragment, riparian forest, and small fragments. We compared capture rates, richness, diversity, similarity, and feeding guilds for the three formations. We captured 418 bats of 12 species belonging to the family Phyllostomidae. The most abundant species was Artibeus planirostris (Spix, 1823) $(\mathrm{n}=126)$. We found no significant differences in capture rate or diversity between the areas, but there were differences in feeding guild representation. Frugivores species were the most abundant in the three areas. No gleaning insectivore or carnivore species were captured in the small fragments, and the large fragment contained no hematophages. The large fragment and the small fragments had the greatest similarity whereas the riparian forest and small fragments had the least similarity.
\end{abstract}

KEYWORDS. Anthropization, Cerrado, fragmentation, savannah.

RESUMO. Assembleia de morcegos filostomídeos (Mammalia: Chiroptera) em uma paisagem modificada no Centro-Oeste do Brasil. Os morcegos são a segunda maior ordem de mamíferos, com diversos hábitos alimentares e grande importância ecológica. A antropização possui diversos efeitos nas comunidades animais e o Cerrado Brasileiro, uma savana neotropical, tem sido severamente afetada pela atividade humana. O objetivo deste estudo foi avaliar a distribuição da assembleia de morcegos filostomídeos nas diferentes formações de paisagem de uma savana modificada. Utilizando redes de neblina, nós realizamos 36 noites de amostragem entre 2015 e 2016. O esforço amostral foi de $23.238 \mathrm{~m}^{2}$.h igualmente distribuído entre três formações de paisagem: um fragmento grande, mata ciliar e pequenos fragmentos. Nós comparamos a taxa de captura, riqueza, diversidade, similaridade e guildas alimentares para as três formações. Foram capturados 418 morcegos de 12 espécies da família Phyllostomidae. A espécie mais abundante foi Artibeus planirostris (Spix, 1823) $(\mathrm{n}=126)$. Nós não encontramos diferenças significativas na taxa de captura ou diversidade entre as áreas, mas houve diferenças na representatividade das guildas alimentares. As espécies frugívoras foram as mais abundantes nas três áreas. Não houve capturas de espécies insetívoras catadoras ou carnívoras nos pequenos fragmentos e de hematófagos no fragmento grande. $\mathrm{O}$ fragmento grande e os pequenos tiveram a maior similaridade entre as formações, enquanto a mata ciliar e os fragmentos pequenos tiveram a menor similaridade.

PALAVRAS-CHAVE. Antropização, Cerrado, fragmentação, savana.

The order Chiroptera consists of more than 1,300 species, almost $25 \%$ of the class Mammalia (Fenton \& Simmons, 2014), and in Brazil there are 184 bat species distributed over 72 genera and nine families (Díaz et al., 2016). There is a wide variety of feeding guilds among bats, including frugivores, pollinivores/nectarivores, carnivores, omnivores, insectivores, piscivores, and hematophages (NORBERG \& RAYNER, 1987). This great feeding diversity enables bats to participate in many ecological roles such as seed dispersal and natural insect control, therefore, they are very important in natural environments (ReIs et al., 2013).

Human activity has reduced the Brazilian Cerrado, a Neotropical savannah, to $20 \%$ of its original cover prior to human intervention (MYers et al., 2000), with its natural formation altered by agriculture (CAVALCANTI \& JOLY, 2002).
Although it is a region with high levels of biodiversity and endemism, only $6.2 \%$ is currently under protection, making it a hotspot for conservation (MYERs et al., 2000).

These human made alterations in the landscape formation has several effects on its biodiversity, with the severity of the impact varying among animal groups (BIERREGAARD et al., 1992). To date, the effects of these environmental changes upon bats remain unclear. While some authors reported more apparent impacts of human activity on bat communities in altered areas, for example species richness and abundance decreased in fragmented areas, and certain species thought to be more resistant to landscape modifications dominated there (Cosson et al., 1999; Medellín et al., 2000; ReIs et al., 2003; MuYLAERT et al., 2016), others found no significant differences in the bat 
communities among areas with varying degrees of human alteration (BERNARD \& FENTON, 2002, 2007; ESTRADA \& Coates-Estrada, 2002).

Since the Brazilian Cerrado has been altered by human activity and bats are very important in natural environments, the objective of this study was to determine the distribution of the bat community in a savannah with different landscape formations such as riparian forest, a large and well-preserved forest fragment, and some small fragments in a pasture matrix. The target region was bounded by the Brazilian Cerrado and the Atlantic Forest in Midwestern Brazil

\section{MATERIAL AND METHODS}

This study was conducted at Fazenda Dona Amélia $\left(22^{\circ} 12^{\prime} \mathrm{S}, 53^{\circ} 28^{\prime} \mathrm{W}\right)$, located $15 \mathrm{~km}$ west of Nova Andradina and southeast of Mato Grosso do Sul, Midwestern Brazil. This region originally had savannah vegetation (Cerrado sensu strictu and Cerradão) with elements of the Atlantic Forest (Potт et al., 2014). Today, however, it contains farming areas such as sugarcane and soy plantations and pastureland (OliveIRA et al., 2000). The climate is Aw according to the Köppen climate classification, characterized as humid tropical with well-defined wet summers and dry winters. The annual precipitation varies from 1,400 to $1,700 \mathrm{~mm}$ and the mean temperature in the coldest month is $>18^{\circ} \mathrm{C}$ (Oliveira et al., 2000).

The studied farm is 3,000 ha in area, 905 ha of which is a legal reserve. The balance consists of pasture and sugarcane plantations. The vegetation is characterized by Cerradão, a forested savannah, with influences of the Atlantic Forest. The landscape has different formations, including a large and well-preserved forest fragment to the north, two riparian forests alongside the streams to the east and west, and several small fragments distributed in a pasture matrix (Fig. 1).

To evaluate the community composition and richness, we sampled three landscape formations. The large fragment (LF) was bounded by the legal reserve north of the farm connected to that of a neighboring farm with an additional 1,800 ha of well-preserved forest. There is little human activity in this area, and it is surrounded by fences preventing cattle from entering. Its few interior trails are utilized only for scientific research purposes. This formation adjoins other well-preserved areas through the riparian forest along the Ivinhema River and its tributaries that connect to this fragment at certain points. The riparian forest (RF) was sampled from two tributary streams of the Ivinhema. It was completely fenced in and cattle were excluded. The small fragments (SF) are several forest fragments with size varying from 1.9 ha to 25 ha distributed in a pasture matrix. They are strongly affected by human activity, and both cattle and people have access to its interior. In this study, we treated SF as a single sampling area (Fig. 1).

Bats were captured at new moon between April 2015 and August 2016. We defined six sampling points in each landscape formation and sampled each of these points once per dry- and wet season. Thus, there were 12 sampling nights per formation. In each sampling night, four mist nets (each $3 \mathrm{~m} \times 9 \mathrm{~m}$ ) were set out on the trails at understory height and remained open for six hours after sunset. We measured the sampling effort according to STRAUBE \& BIANCONI (2002), with $23,328 \mathrm{~m}^{2}$.h equally distributed among the three formations, and inspected the nets every $15 \mathrm{~min}$. Since the individuals caught were not marked, some may have been recaptures. Nevertheless, recapturing occurs only infrequently with neotropical bats (MEDELLín et al., 2000; BERNARD \& FENTON, 2003) and probably did not influence the results.

The bats were classified according to their feeding habits and the literature available on the species (REIS et $a l ., 2013)$. The feeding guild categories were frugivores, nectarivores, omnivores, gleaning insectivores, carnivores and hematophages.

The captured individuals were classified using identification keys available in the literature (CHARLESDOMINIQUE et al., 2001; MirANDA et al., 2011). Bat forearm size, weight, and sex were noted. Those that could not be reliably identified in the field were collected and identified a posteriori through cranial characteristics. One individual from each bat species was set aside as a voucher. These were deposited in the Coleção Zoológica de Referência da Universidade Federal de Mato Grosso do Sul (ZUFMS, No. CHI02311-CHI02428). The collections were authorized by the Instituto Chico Mendes de Conservação de Biodiversidade (ICMBio) (License No. 50642-1). The animals were sacrificed by cervical dislocation according to Protocol No. 728/2015 approved by the Comissão de Ética no Uso de Animais da Universidade Federal de Mato Grosso do Sul (CEUA/ UFMS).

The capture rate was determined from the number of bat captures / nights of sampling for each formation. To verify differences in capture rate between formations, we utilized the Kruskal-Wallis test if the distribution was non-normal, with normality evaluated with the Shapiro-Wilkinson test. For the expected number of species, we used the Chao-1 index, and to evaluate assemblage diversity in the formations, we utilized the Shannon-Wiener (H') index. Student's $t$-test was used to identify differences between diversity levels. For each formation, we determined the percentage of bats in each feeding guild, the most abundant species, and the number of rare species ( $\mathrm{N}<5$ in all formations combined).

To find bat community similarity among the three formations, we utilized the Bray-Curtis similarity index. We also performed a community ordination using Non-Metric Multidimensional Scaling (NMDS). Each sampling point was taken as a community.

\section{RESULTS}

We captured 418 phyllostomid bats from 12 species and five subfamilies. The riparian forest (RF) had the greatest richness (ten species), while both in the large (LF) and small (SF) fragments nine species were recorded. The values were 
close to the estimated through Chao-1 index $(\mathrm{RF}=10, \mathrm{LF}$ $=9.5, \mathrm{SF}=10.5$ ).

The capture rates measured in this study were as follows: riparian forest, 12.5 bats / night; large fragment, 12.4 bats / night; and small fragments, 11.6 bats / night. The Kruskal-Wallis test showed no significant differences in capture rate among the three landscape formations ( $\mathrm{LF} x$ $R F: p=0.43$; LF $x$ SF: $p=0.86$; RF $\times$ SF: $p=0.19$ ).

The diversity H' was 1.61 for the large fragment, 1.73 for the riparian forest, and 1.53 for the small fragments. There were no significant differences in the diversity of the three formations (LF $x$ RF: $p=0.28$; LF $x$ SF: $p=0.36$; RF x SF: $p=0.06)$.

The similarity ratings between formations were as follows: large fragment and riparian forest, 0.55 ; large fragment and small fragments, 0.62 ; riparian forest and small fragments, 0.35 . The NMDS were similar to the above; most of the riparian forest sampling points were far from those of the small fragments whereas the large fragment sampling points were close to both of these formations (Fig. 2).

Frugivores, nectarivores and omnivores bats were recorded for all three formations. Gleaning insectivores and carnivores were not found in the small fragments, and no hematophages were detected in the large fragment. All the frugivores and nectarivores species were found in all three landscape formations (Tab. I).

More than half of the captures in all three formations were frugivores. A total of 271 were caught at all three formations (64.8\% of all captures). The frugivores accounted for $80.7 \%$ of the captures in the small fragments, $66.0 \%$ in the riparian forest, and $51.0 \%$ in the large fragment. The nectarivores were the second most abundant guild. There was a total of 82 captures (19.6\%), of which 47 were caught in the large fragment $(31.5 \%)$ and 33 in the riparian forest $(22.0 \%)$. Omnivores were found mostly in the large fragment and the small fragments and accounted for $15.0 \%$ of the total captures in each formation. Gleaning insectivores represented $2.0 \%$ of the captures in the large fragment and $1.3 \%$ in the riparian forest, while the only carnivore captured was from the riparian forest. Hematophages represented $8.7 \%$ of the total capture in the riparian forest and $2.0 \%$ in the small fragments (Tab. I).

The most frequently captured species was Artibeus planirostris ( $\mathrm{n}=126$, or $30.14 \%$ of the total). It was the most abundant species in both the large fragment $(n=49)$ and the small fragments $(\mathrm{n}=52)$. In the riparian forest, the most abundant species was Carollia perspicillata $(\mathrm{n}=57)$, and in total it was also the third most frequently captured species (n $=69 ; 16.51 \%$ ). Glossophaga soricina was the second most abundant species in all three formations $(\mathrm{n}=82 ; 19.62 \%)$.

There were two rare species of gleaning insectivore (Micronycteris megalotis and Lophostoma brasiliense), one of carnivore (Chrotopterus auritus) and one of omnivore (Phyllostomus discolor). The large fragment had M. megalotis and L. brasiliense, and the riparian forest had M. megalotis and $C$. auritus. The only rare species in the small fragments was $P$. discolor.

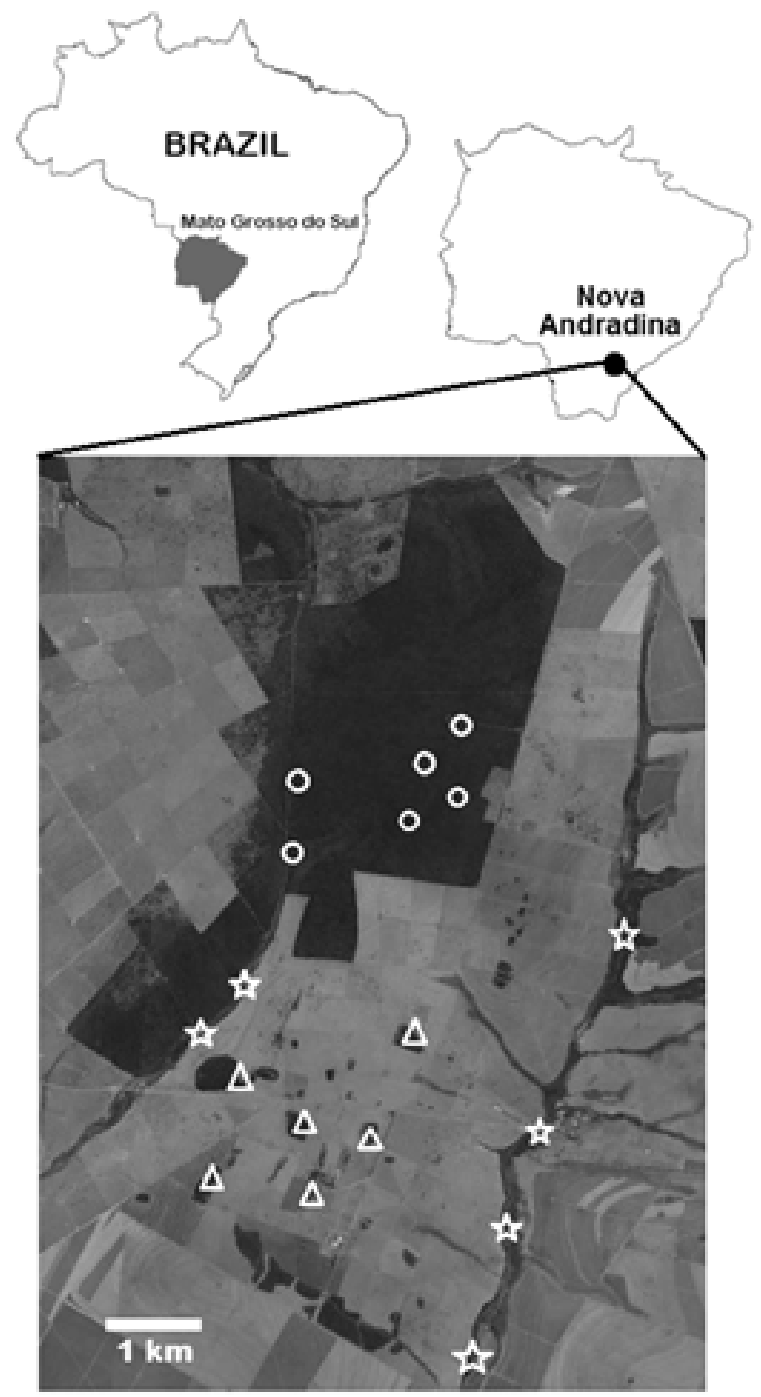

Fig. 1. Sampling points at Fazenda Dona Amélia, Mato Grosso do Sul, Brazil (circles, points in the large fragment; stars, points in the riparian forest; triangles, points in the small fragments).

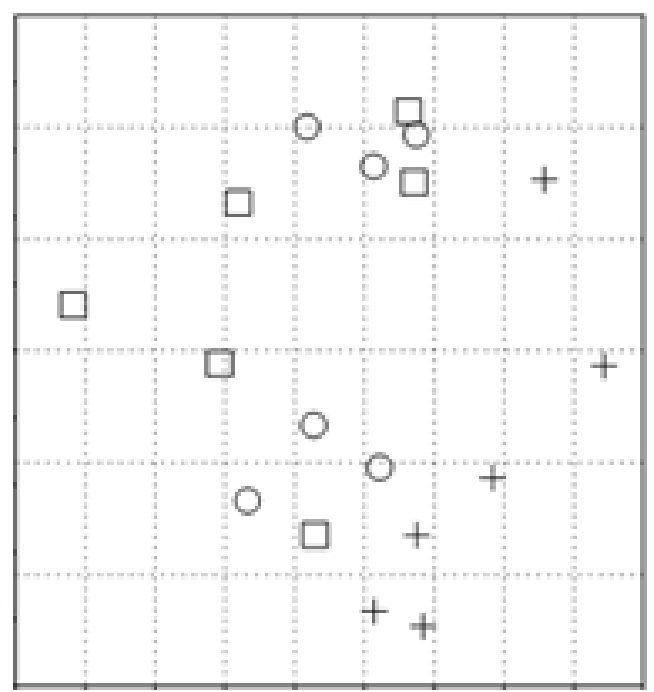

Fig. 2. Similarity between the sampling points of the three landscape formations indicated by the NMDS method (circle, large fragment; square, riparian forest; cross, small fragments). 
Tab. I. Number of phyllostomid bats captured at Fazenda Dona Amélia, Mato Grosso do Sul, Brazil according to feeding guild and species, with percentage relative to the total captures at the landscape formation (LF, large fragment; RF, riparian forest; SF, small fragments; *, rare species).

\begin{tabular}{|c|c|c|c|c|c|c|c|c|}
\hline \multirow{2}{*}{ Feeding guilds / species } & \multicolumn{2}{|c|}{ LF } & \multicolumn{2}{|c|}{$\mathrm{RF}$} & \multicolumn{2}{|c|}{ SF } & \multicolumn{2}{|c|}{ Total } \\
\hline & $\mathrm{n}$ & $\%$ & $\mathrm{n}$ & $\%$ & $\mathrm{n}$ & $\%$ & $\mathrm{n}$ & $\%$ \\
\hline \multicolumn{9}{|l|}{ Frugivores } \\
\hline Artibeus planirostris & 49 & 32.9 & 25 & 16.7 & 52 & 43.7 & 12.6 & 30.1 \\
\hline Artibeus lituratus & 12 & 8.0 & 6 & 4.0 & 25 & 21.0 & 43 & 10.3 \\
\hline Platyrrhinus lineatus & 3 & 2.0 & 4 & 2.7 & 1 & 0.8 & 8 & 1.9 \\
\hline Sturnira lilium & 1 & 0.7 & 7 & 4.7 & 17 & 14.3 & 25 & 6.0 \\
\hline \multirow[t]{2}{*}{ Carollia perspicillata } & 11 & 7.4 & 57 & 38.0 & 1 & 0.8 & 69 & 16.5 \\
\hline & 76 & 51.0 & 99 & 66.0 & 96 & 80.7 & 271 & 64.8 \\
\hline \multicolumn{9}{|l|}{ Nectarivores } \\
\hline \multirow[t]{2}{*}{ Glossophaga soricina } & 47 & 31.5 & 33 & 22.0 & 2 & 1.7 & 82 & 19.6 \\
\hline & 47 & 31.5 & 33 & 22.0 & 2 & 1.7 & 82 & 19.6 \\
\hline \multicolumn{9}{|l|}{ Omnivores } \\
\hline Phyllostomus discolor* & 0 & 0.0 & 0 & 0.0 & 1 & 0.8 & 1 & 0.2 \\
\hline \multirow[t]{2}{*}{ Phyllostomus hastatus } & 23 & 15.4 & 2 & 1.3 & 17 & 14.3 & 42 & 10.0 \\
\hline & 23 & 15.4 & 2 & 1.3 & 18 & 15.1 & 43 & 10.3 \\
\hline \multicolumn{9}{|l|}{ Animalivores } \\
\hline Lophostoma brasiliense* & 1 & 0.7 & 0 & 0.0 & 0 & 0.0 & 1 & 0.2 \\
\hline Micronycteris megalotis* & 2 & 1.3 & 2 & 1.3 & 0 & 0.0 & 4 & 1.0 \\
\hline \multirow[t]{2}{*}{ Chrotopterus auritus* } & 0 & 0.0 & 1 & 0.7 & 0 & 0.0 & 1 & 0.2 \\
\hline & 3 & 2.0 & 3 & 2.0 & 0 & 0.0 & 6 & 1.4 \\
\hline \multicolumn{9}{|l|}{ Hematophages } \\
\hline \multirow[t]{2}{*}{ Desmodus rotundus } & 0 & 0.0 & 13 & 8.7 & 3 & 2.5 & 16 & 3.8 \\
\hline & 0 & 0.0 & 13 & 8.7 & 3 & 2.5 & 16 & 3.8 \\
\hline Total captures & \multicolumn{2}{|c|}{149} & \multicolumn{2}{|c|}{150} & \multicolumn{2}{|c|}{119} & \multicolumn{2}{|c|}{418} \\
\hline Richness & \multicolumn{2}{|c|}{9} & \multicolumn{2}{|c|}{10} & \multicolumn{2}{|c|}{9} & \multicolumn{2}{|c|}{12} \\
\hline
\end{tabular}

\section{DISCUSSION}

No significant differences in bat formations were detected among the landscape formations of Fazenda Dona Amélia through the statistical analysis, however there was some variations in species specific utilization. This observation suggests that most of the bat species from the assemblage utilize the resources of the various formations equally and nonselectively. However, analyzing more deeply, the small fragments seems to be more restrictive to some species that are more sensitive to habitat alteration. Similar results were reported for other regions (ESTRADA \& COATESEstrada, 2002; Faria, 2006; Bernard \& Fenton, 2007). The ability of bats to occupy different landscape formations in similar ways is probably explained by their high dispersion capacity (ESTRADA \& COATES-EsTRADA, 2002). For certain animal species, open areas such as pasture matrices are barriers (BIERREGAARD et al., 1992; TURNER \& CORLETT, 1996). Nevertheless, this restriction does not seem to apply to bats, as verified by BERNARD \& FENTON (2003) in the northern Brazil, where they can cross wide expanses of open savannah. The amount of time that has passed since an area was deforested also determines how effectively bats can utilize it (Bernard \& Fenton, 2003), and at Fazenda Dona Amélia the natural vegetation was converted to pasture decades ago, so time may have attenuated the perturbation caused by the open areas.
The similarity of the three landscape formations probably was more influenced by the representativeness of the species in the sample of each formation than by the species sharing. The large and the small fragments, despite being very different in some characteristics, such edge area and anthropization degree, had a high degree of similarity because certain species such as Artibeus planirostris and Phyllostomus hastatus were strongly represented in both. These bat species utilize both undisturbed and disturbed forest and were very abundant in both formations. The riparian forest and the small fragments both have large perimeters, and both the forest and the large fragment have relatively low levels of disturbance. Despite the traits common to the forest and the fragments, there was, in fact, relatively greater similarity in the bat communities of the large- and small fragments. Carollia perspicillata was very abundant in the riparian forests but relatively rare in the other two formations. Conversely, $P$. hastatus and A. planirostris were far more numerous in the large- and small fragments than the riparian forest.

Although there were no apparent significant differences in abundance or diversity among the three landscape formations, the analysis of the feeding guild and species data indicates some variations.

The distribution of the frugivores species was variable, with the most abundant of the larger frugivores being Artibeus spp. and their presence varying in preserved areas. Some authors reported higher capture numbers for this genus in undisturbed areas (MedelLín et al., 2000; SCHULZE 
et al., 2000; FARIA, 2006) and others in more disturbed areas (GorResen \& Willig, 2004). We encountered these species in all environments, but most of the captures occurred in the large and small fragments. This result may be explained by the feeding habits of these species. Artibeus spp. usually prefer a diet based on canopy fruits such as Ficus (HANDLEY et al., 1991), which accounts for their presence in areas with primary vegetation. EsTRADA \& COATES-ESTRADA (2002) proposed that bats from genus Artibeus may include in their daily foraging range several forest fragments and patches of other vegetation, since they can fly high distances, over $10 \mathrm{~km}$ from roosts to feeding sites (MORRISON, 1978), what is supported by GoRRESEN \& WILLIG (2004), that proposes these bats forage in small fragments to supplement their primary forest diet.

Some studies reported that smaller understory-foraging frugivores such as Sturnira lilium, Carollia perspicillata and Platyrrhinus lineatus dominate in disturbed areas because of the food availability, since they feed on pioneer plants (Medellín et al., 2000; SchUlze et al., 2000; Estrada \& Coates-Estrada, 2002; Faria, 2006). At Fazenda Dona Amélia, we detected $P$. lineatus in all three formations but only at low capture numbers. It was difficult to evaluate the variations in the habitat use of $P$. lineatus because it accounted for $<3 \%$ of all captures.

Sturnira lilium was found in all three landscape formations, primarily in the small fragments, few specimens in the riparian forest, and only one individual in the large fragment. These findings corroborate those reported in other studies despite the fact that it was not the most abundant species in small and modified fragments as in Mexico (Medellín et al., 2000) and Guatemala (Schulze et al., 2000). In both cases, Sturnira lilium predominated in disturbed areas because, according to the authors, of their diet, since the species feeds on pioneer plants like Piperaceae and mainly on Solanaceae (MelLo et al., 2008), which establish in disturbed areas and are relatively rare in the interior of undisturbed forests such as the large fragment at Fazenda Dona Amélia.

Carollia perspicillata predominated in the riparian forest, was relatively rare in the large fragment and one specimen was collected in the small fragments. Like S. lilium, it feeds on the fruit of pioneer plants and was expected to have a large presence in the small fragments. Nevertheless, MedelLín et al. (2000) reported that this species is more abundant in moderately- than highly disturbed area, FARIA (2006) reported high captures rates of the species at secondary forest and shade cocoa plantations, while the species was captured in similar rates to all environments by ESTRADA \& Coates-Estrada (2002). Gorresen \& Willig (2004) proposed that the relatively greater roost availability in moderately altered areas may account for this discrepancy. According to the authors, this species may feed on several different types of fruit and would, therefore, explore various environments. For this reason, its foraging requirement would be low, but it would still have to compete for the safest roosts available and favor areas with at least some intact vegetation. The species may have preferred the riparian forests of Fazenda Dona Amélia because it has well-preserved vegetation in the center and near the river, highly diverse environments, and pioneer plants along the borders.

The only nectarivores bat species identified in this study was Glossophaga soricina. It was found primarily in the large fragment and the riparian forests, and few individuals were caught in the small fragments. GoRRESEN \& WILLIG (2004) reported similar findings, indicating that this species was more abundant in larger and closer fragments and more sparsely distributed in smaller and more isolated areas. Other studies, however, stated that it occurred in relatively higher numbers in disturbed areas (SIMMONS \& Voss, 1998; EsTRADA \& Coates-Estrada, 2002). Resource-rich areas support smaller living spaces, shorter flights, and lower foraging energy expenditures, therefore, the G. soricina of Fazenda Dona Amélia may have favored the large fragment and the riparian forest because maybe resources were more plentiful there.

The omnivores species recorded at Fazenda Dona Amélia, are phyllostomines, subfamily pointed by MedelLín et al. (2000) as indicators of undisturbed areas. However, this two species seem to adapt to disturbed areas as well, with WILsON et al. (1996) describing P. hastatus as an indicator of disturbed areas. In this study, $P$. hastatus was very abundant both in the large fragment and the small fragments. Therefore, it is more likely that it utilizes diverse environments rather than concentrating in disturbed areas. We could draw no conclusions regarding $P$. discolor because we only captured one individual of this species. It is likely, however, that its behavior resembles that of $P$. hastatus (Simmons \& Voss, 1998). Differences in landscape utilization among the other Phyllostominae species may be explained by their feeding habits. While the feeding habits of other phyllostomines are highly specialized (MedelLín et al., 2000), P. hastatus is a generalist and can feed on fruit (WILSON et al., 1996), insects (WILLIG et al., 1993), nectar (GriBEL \& HAY, 1993), and small vertebrates (GoODWIN \& GREENHALL, 1961).

Gleaning insectivore bats were not captured in the small fragments. Other studies reported that species with this habit were rare in the Neotropical region (MEDELLín et al., 2000; FARIA, 2006), nonetheless, we captured three bats species from this guild in the riparian forest and the large fragment. All of the gleaning insectivore species identified in this study belong to the subfamily Phyllostominae. MedELLín et al. (2000) stated that this taxon is an indicator of wellpreserved areas and correlated the relative abundance of phyllostomines with their high feeding specificity, since several species in this subfamily are carnivores or gleaning insectivores which capture insects on leaves and other surfaces. Other factors influencing Phyllostominae abundance are high sensitivity to border effects and low mobility (MEYER et al., 2008). These characteristics are particularly applicable to the smaller gleaning insectivores such as Micronycteris megalotis and Lophostoma brasiliense reported in this study. Species with this feeding habit and smaller size usually occupy smaller areas, forage near their roosts, and fly shorter 
distances (BERNARD \& FENTON, 2003). The pasture matrix between the small fragments and the other formations may have made it difficult for these species to utilize this area.

The only carnivore species captured, Chrotopterus auritus was captured in the riparian forest. This species is also members of Phyllostominae, and so presumably sensitive to forest disturbance, as cited before, and the restrictions they are subject to in disturbed ambient are similar to those of the gleaning insectivores (MEDELLÍn et al., 2000), however as they are large bats, big distances are not a great barrier for them. According to GoRRESEN \& WILLIG (2004), food availability is not the main limiting factor for C. auritus, but the capture success, provided by the well-preserved forests and with a more pronounced vertical structure and proper to the arboreal foraging habits of this species.

The presence and distribution of Desmodus rotundus at Fazenda Dona Amélia may be explained by its feeding habit, since it consumes the blood of large mammals (AGUIAR, 2007) and presents a high degree of preference for cattle despite the presence of native animals (FENTON, 1992; VoIGT \& Kelm, 2006), and Fazenda Dona Amélia breeds cattle, providing a suitable feeding area for the hematophages. The species was observed in the riparian forest and the small fragments but was absent in the large fragment, and cattle distribution accounts for this difference. The small fragments are surrounded by pasture matrix where cattle can graze and to which $D$. rotundus has easy access. These bats can also reach the open areas around the fragments where they can forage as well. In addition, this bat species is highly mobile and is known to travel more than $10 \mathrm{~km}$ within an area (MALAGA-AlbA, 1954; WiLKINSON, 1985). The riparian forests are close to cattle breeding areas and may also serve as a flight route since $D$. rotundus usually flies along the same habitual paths (MitcheLL et al., 1973). The large fragment, however, is located at the northern limit of the farm and is quite remote from the cattle.

As shown above, the landscape formations had some variations in the species presence. The small fragment was more restrictive to some species, like the gleaning insectivore and carnivore bats captured in this study, due to their highly specific feeding niche, and had a higher dominance of species less sensitive to habitat disturbance, like $A$. planirostris, $A$. lituratus, $S$. lilium and $P$. hastatus, that added represent almost the total of bats in this formation. The large fragment and the riparian forest had almost the same richness of the small fragments, however they had less dominance of few species, had less presence of disturbed ambient species, like S. lilium, and both had presence of the gleaning insectivores and carnivore species from the Phyllostominae, indicating a higher capacity of this formations to be utilized by a more diverse assemblage.

In summary, the habits of the bat species sampled in the three landscape formations at Fazenda Dona Amélia indicated that the areas had similar bat assemblages, with the small fragments being more restrictive to some species, and the large fragments and the riparian forest more able to maintain a more diverse community.
Acknowledgments. We thank CAPES and FUNDECT for their financial assistance and the management and staff of Fazenda Dona Amélia for their logistic support.

\section{REFERENCES}

Aguiar, L. M. DE S. 2007. Subfamília Desmodontinae. In: ReIs, N. R.; Peracchi, A. L.; Pedro, W. A. \& Lima, I. P. eds. Morcegos do Brasil. Londrina, Universidade Estadual de Londrina, p. 39-43.

Bernard, E. \& Fenton, M. B. 2002. Species diversity of bats (Mammalia: Chiroptera) in forest fragments, primary forests, and savannas in central Amazonia, Brazil. Canadian Journal of Zoology 80:1124-1140.

Bernard, E. \& Fenton, M. B. 2003. Bat mobility and roosts in a fragmented landscape in central Amazonia, Brazil. Biotropica 35:262-277.

Bernard, E. \& Fenton, M. B. 2007. Bats in a fragmented landscape: Species composition, diversity and habitat interactions in savannas of Santarém, Central Amazonia, Brazil. Biological Conservation 134:332-343.

BierregaArd, R. O.; Lovejoy, T. E.; Kapos, V.; Santos, A. A. \& Hutchings, R. W. 1992. The biological dynamics of tropical rainforest fragments: a prospective comparison of fragments and continuous forest. BioScience 42:859-866.

Cavalcanti, R. B. \& Joly, C. A. 2002. Biodiversity and Conservation Priorities in the Cerrado Region. In: Oliveira, P. S. \& MARQuis, R. J. eds. The Cerrados of Brasil: Ecology and Natural History of a Neotropical Savanna. New York, Columbia University Press, p. 351-368.

Charles-Dominique, P.; Brosset, A. \& Jouard S. 2001. Les Chauvessouris de Guyane. Paris, Muséum National d'Histoire Naturelle. 172p.

Cosson, J. -F.; Pons, J. -M. \& Masson, D. 1999. Effects of forest fragmentation on frugivorous and nectarivorous bats in French Guiana. Journal of Tropical Ecology 15:515-534.

Díaz, M. M.; Solari, S.; Aguirre, L. F.; Aguiar, L. M. S. \& Barquez, R. M. 2016. Clave de identificación de los murciélagos de Sudamerica. Tucumán, Programa de Conservación de los Murciélagos de Argentina. $80 \mathrm{p}$.

EstradA, A. \& CoATes-Estrada, R. 2002. Bats in continuous forest, forest fragments and in an agricultural mosaic habitat island at Los Tuxtlas, Mexico. Biological Conservation 103:237-245.

FARIA, D. 2006. Phyllostomid bats of a fragmented landscape in the northeastern Atlantic forest, Brazil. Journal of Tropical Ecology 22:531-542.

Fenton, M. B. 1992. Wounds and the origin of blood-feeding in bats. Biological Journal of the Linnean Society 47:161-171.

Fenton, M. B. \& Simmons, N. B. 2014. Bats: A World of Science and Mystery. Chicago, University of Chicago Press. 240p.

Goodwin, G. G. \& Greenhall, A. M. 1961. A review of the bats of Trinidad and Tobago: description, rabies infection and ecology. Bulletin of the American Museum of Natural History 122:187-301.

Gorresen, P. M. \& Willig , M. R. 2004. Landscape Responses of Bats To Habitat Fragmentation in Atlantic Forest of Paraguay. Journal of Mammalogy 85:688-697.

Gribel, R. \& HaY, J. D. 1993. Pollination ecology of Caryocar brasiliense (Caryocaraceae) in Central Brazil cerrado vegetation. Journal of Tropical Ecology 9:199-211.

Handley, C. O.; Wilson , D. E. \& Gardner, A. L. 1991. Demography and natural history of the common fruit bat, Artibeus jamaicensis, on Barro Colorado Island, Panamá. Smithsonian Contributions to Zoology:1-173.

Malaga-Alba, A. 1954. Vampire bat as a carrier of rabies. American Journal of Public Health 44:909-918.

Medellín, R. A.; Equinua , M. \& Amin, M. A. 2000. Bat diversity and abundance as indicators of disturbance in neotropical rainforest. Conservation Biology 14:1666-1675.

Mello, M. A. R.; Kalko, E. K. V. \& Silva, W. R. 2008. Diet and abundance of the bat Sturnira lilium (Chiroptera) in a Brazilian Montane Atlantic Forest. Journal of Mammalogy 89:485-492.

Meyer, C. F. J.; Fründ, J.; Lizano, W. P. \& Kalko, E. K. V. 2008. Ecological correlates of vulnerability to fragmentation in Neotropical bats. Journal of Applied Ecology 45:381-391.

Miranda, J. M. D.; Bernardi, I. P. \& Passos, F. C. 2011. Chave ilustrada para a determinação dos morcegos da Região Sul do Brasil. Curitiba, João M. D. Miranda. 51p. 
The phyllostomid bat (Mammalia, Chiroptera) assemblage...

Odon et al.

Mitchell, G. C.; Burns, R. J. \& Kolz, A. L. 1973. Rastreo del comportamiento nocturno de los murciélagos vampiros por radiotelemetria. Tecnica Pecuaria en Mexico 24:47-56.

MorRison, D. W. 1978. Foraging Ecology and Energetics of the Frugivorous Bat Artibeus jamaicensis. Ecology 59:716-723.

Muylaert, R. L.; Stevens, R. D. \& Ribeiro, M. C. 2016. Threshold effect of habitat loss on bat richness in cerrado-forest landscapes. Ecological Applications 26:1854-1867.

Myers, N.; Mittermeier, R. A.; Mittermeier, C. G.; Fonseca, G. A. B. \& KENT, J. 2000. Biodiversity hotspots for conservation priorities. Nature 403:853-858.

NORBERG, U. M. \& RAYNER, J. M. V. 1987. Ecological Morphology and Flight in Bats (Mammalia, Chiroptera): wing adaptations, flight performance, foraging strategy and echolocation. Philosophical Transactions of the Royal Society of London 316:335-427.

Oliveira, H.; Urchei, M. A. \& Fietz, C. R. 2000. Aspectos físicos e socioeconômicos da bacia hidrográfica do rio Ivinhema. Dourados, Embrapa Agropecuária Oeste. 52p.

Potт, A.; Silva, J. S. V. \& Gomes, E. L. 2014. Características da Bacia Hidrográfica do Rio Ivinhema. Revista GeoPantanal:109-124.

Reis, N. R.; Barbieri, M. L. D. S.; Lima, I. P. \& Peracchi A. L. 2003. O que é melhor para manter a riqueza de espécies de morcegos (Mammalia, Chiroptera): um fragmento florestal grande ou vários fragmentos de pequeno tamanho? Revista Brasileira de Zoologia 20:225-230.

Reis, N. R.; Fregonezi, M. N.; Peracchi, A. L. \& Shibatta, A. O. 2013. Morcegos do Brasil: Guia de Campo. Rio de Janeiro, Technical Books. 252p.
Schulze, M. D.; Seavy, N. E. \& Whitacre, D. F. 2000. A comparison of the phyllostomid bat assemblages in undisturbed neotropical forest and in forest fragments of a slash-and-burn farming mosaic in Petén, Guatemala. Biotropica 32:174-184.

Simmons, N. B. \& Voss, R. S. 1998. The Mammals of Paracou, French Guiana: a neotropical lowland rainforest fauna Part 1. Bats. Bulletin of the American Museum of Natural History 237:1-219.

Straube, F. C. \& Bianconi, G. V. 2002. Sobre a grandeza e a unidade utilizada para estimar esforço de captura com utilização de redes-deneblina. Chiroptera Neotropical 8:150-152.

Turner, I. M. \& Corlett, R. T. 1996. The conservation value of small, isolated fragments of lowland tropical rain forest. Trends in Ecology \& Evolution 11:330-333.

Voigt, C. C. \& Kelm, D. H. 2006. Host preference of the common vampire bat (Desmodus rotundus; Chiroptera) assessed by stable isotopes. Journal of Mammalogy 87:1-6.

WiLKINSON, G. S. 1985. The social organization of the common vampire bat - I. Pattern and cause of association. Behavioral Ecology and Sociobiology 17:111-121.

Willig, M. R.; Camilo, G. R. \& Noble, S. J. 1993. Dietary overlap in frugivorous and insectivorous bats from edaphic cerrado habitats of Brazil. Journal of Mammalogy 74:117-128.

Wilson, D. E.; AsCorra, C. F. \& Solari, S. 1996. Bats as indicators of habitat disturbance. In: Wilson, D. E. \& SANDOval, A. eds. Manu: The biodiversity of southeastern Peru. Washington D. C., Smithsonian Institution, p.613-626.

Iheringia, Série Zoologia, 109: e2019015

7 